\title{
阿寺断層付近の低い地震活動
}

\author{
名古屋大学理学部地球科学教室 伊神 煇 - 安久 勉・青木治三 \\ (昭和 47 年 5 月 29 日受理)
}

\section{Low Seismic Activity Associated with the Atera Fault, Central Japan}

\author{
Akira IKamI, Tsutomu ANKYu and Harumi AoKI \\ Department of Earth Sciences, Faculty of Science, \\ Nagoya University
}

(Received May 29, 1972)

\begin{abstract}
An observation of microearthquakes was carried out near the Atera Fault for two and a half months, from July 14 to October 2, 1971, since the fault has been known as one of the most active faults in Japan.

In the south-western side of the Atera Fault, the focal depths of earthquakes were deeper than $30 \mathrm{~km}$, that is, earthquakes occurred in the mantle but not in the crust. In the northeastern side, however, only a few earthquakes were detected. Although three direct analogue recording systems of high sensitivity were used near the fault, very few earthquakes could be located near the fault. A comparison of daily frequency of earthquakes near the NeoValley Fault with the present observation showed that the seismicity near the Atera Fault was undoubtedly lower than that near the Neo-Valley Fault. The same tendency has been also observed for larger earthquakes. Number of earthquakes detected at one of the three stations was exceptionally large, though the sensitivity was the same for all stations. But most of distant earthquakes were equally detected.

Considering these facts, it might be concluded that the present seismic activity is very low and, in addition, seismic waves of high frequency are attenuated in the crust near the Atera Fault. Some focal mechanisms of microearthquakes were calculated. The pressure axis thus obtained was E-W direction as in the case studied by MATSUDA (1969) and ICHIKAWA (1971).
\end{abstract}

\section{$\S 1$. 結 論}

阿寺断層付近の地震活動調查については, 渡辺・飯田 (1970), 松村 (1971) の報告があり，そ の後, 1970 年 3 月に約 2 週間にわたつて阿寺断層南東端の地域で観測を実施したことがある (未発表).これらの観測の結果，この阿寺断層付近の現在の地震活動は隣接している根尾谷断 層にくらべて小さいことが指摘されてきた. SUGIMURA and MATSUDA (1965) によれば, こ の阿寺断層はその端を長野県恵那山の麓に発し，北西方向に $60 \mathrm{~km}$ 以上ものびている断層で

昭和 47 年 4 月 20 日地震学会春季大会にて発表. 
あり，その変位量は上下成分よりも水平成分のほうが卓越している左横ずれ断層であり，その 水平成分の变位量は平均 $8 \mathrm{~km}$ にも達しているという。またこの断層は現在から約 $1.5 \times 10^{6}$ 年前に活動を始め, 断層運動の水平方向の变位速度は $5 \mathrm{~mm} /$ 年 であるとの報告がある(松田, 1969). 阿寺断層も根尾谷断層も, ともに, 地質学的地形学的にみて第 1 級の活断層といわれて いるが根尾谷断層は 1891 年の濃尾地震 (マグニチュード 8.4) のさいに変位したことで有名 であり, 現在の根尾谷断層付近の地震活動は, この濃尾地震の余震であると指摘されている. たとえば UTSU（1969）によつて，この濃尾地震の余震活動は現在に至るまで 80 年間以上に わたつて, $p=1.05$ の改良大森公式に従つて減衰しているとの報告がある. 阿寺断層と根尾谷

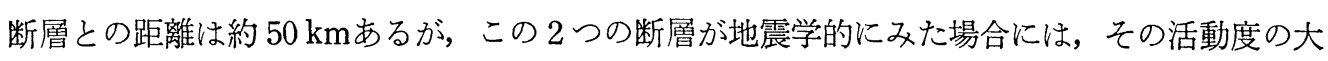
きさに差異がある。また地質学的にみた場合にはその活動度の大きさは，阿寺断層のほうがよ

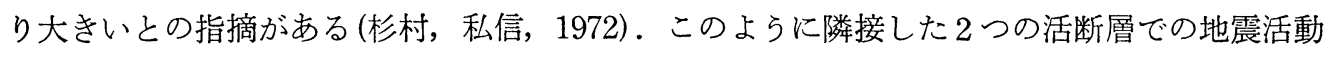
度の羑異は何によるのであろらか. 杉村 (1972) が指摘するように根尾谷断層が偶然 1891 年 に発生し，現在なおそ括の余震活動がつづいており，改良大森公式にあてはまつているのか， たは根尾谷断層の現在の地震活動は定常的なものとみなしよいのかといら問題点があると思わ れる. 今回は上記のように現在地震活動の小さな地域で, その様子がどうなつているかを調べ るために長期間にわたり観測可能な器機を製作し（伊神・青木, 1972), 阿寺断層南東端の地 域において，1971 年 7 月 14 日より 10 月 2 日をで観測を実施したので報告する.

\section{$\S 2$. 中部地方の地震活動}

ある地域の地震活動が低いことを確認するためには, 長期間にわたり観測される地震数が少 ないことのほかに，その地域での地震波の減衰により観測できなくなる可能性も考慮しなけれ ばならない，後者の問題は $\S 5$. で論じよう。

阿寺断層付近の地震活動の低さを示すために，まず一例として微小地震活動をみてみる．名 古屋大学理学部付属犬山地震観測所および衛星観測点である真福寺は, ともに根尾谷断層の南 東端に位置しているが，この両観測点で記録された S-P 時間が 15 秒以下のものの一日あた りの地震数の平均と今回の観測の結果および渡辺・飯田 (1970), 村松 (1971) の結果とを合わ せて表にしたものを Table 1 に示す。この表からわかるように犬山地震観測所と真福寺での 一日あたりの地震数に比べて, 阿寺断層付近に設置した上記 7 臨時観測点での地震数の少なさ に注目でき，根尾谷断層付近に比べていかにこの阿寺断層付近の地震活動が低いかがわかるで あろう。

またこの中部地方における有史以来の被害地震の震央を図示すると, Fig. 1 に示すように 
なる.この図から阿寺断層の付近で, 一番この断層近くに発生したものは, 762 年の地震（マ グニチュード 7.4）であることがわる。 また 1969 年 9 月に岐阜県中部に発生した地震（マグ

Table 1. Number of earthquakes per day. Sensitivity: Kitabayashi, Iwakura and Tozawa $; 4 \mathrm{~mm} / 100 \mu$ kine, Sakashita; $1 \mathrm{~mm} /$ $100 \mu$ kine, other stations; $2 \mathrm{~mm} / 100 \mu \mathrm{kine}$ (after WATANABE, S. and K. IIDA(1970) and Muramatsu, I. (1971), except Kitabayashi, Iwakura and Tozawa).

\begin{tabular}{|clc|}
\hline Station & Data of observation & $\begin{array}{c}\text { Number } \\
\text { per day }\end{array}$ \\
\hline Kitabayashi July14,1971-0ct. 1,1971 & 4.5 \\
Iwakura & July15,1971-Sep. 4,1971 & 3.2 \\
& Sep.13,1971-Sep.22,1971 & \\
Tozawa & Ju1y15,1971-0ct. 2,1971 & 2.3 \\
Tsukechi & July23,1968-Aug. 5,1968 & 1.5 \\
& Sep.4,1970-Nov. 3,1970 & 3.1 \\
Sakashita & Sep.18,1970-Nov.27,1968 & 2.3 \\
Norimasa & Sep.4,1970-Nov. 3,1970 & 3.4 \\
Sami & Sep.4,1970-Nov. 3,1970 & 2.3 \\
Shinpukuzi & Sep.4,1970-Nov. 3,1970 & 11.9 \\
Inuyama & Sep.18,1968-Nov.27,1968 & 10.0 \\
\hline
\end{tabular}

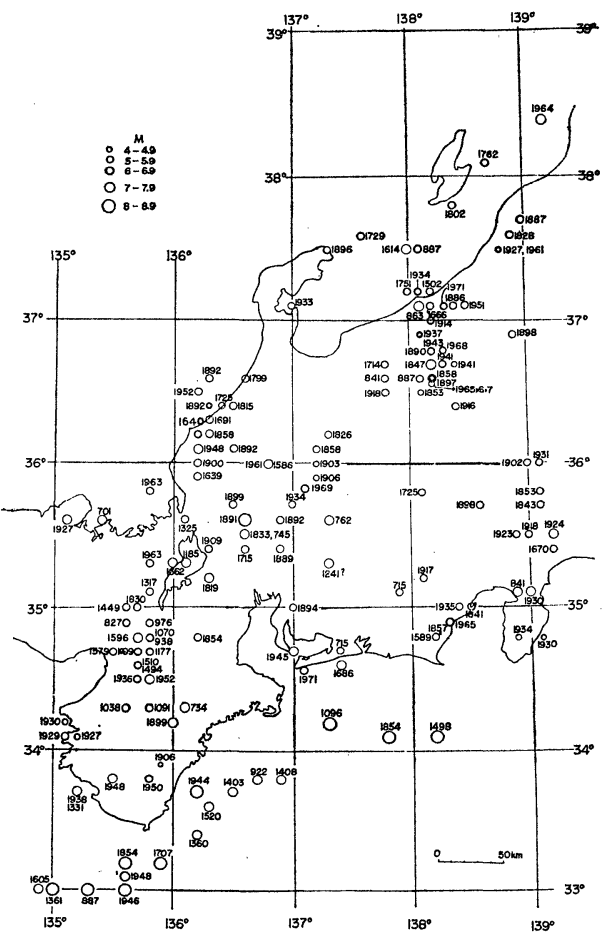

Fig. 1. Distribtion of epicenters of large earthquakes in central Japan (after IIDA, K., 1972).
ニチュード 6.6） も阿寺断層に近いとこ ろで発生しているが，笠原等 (1970) に よつて光波測量が実施されて和り，阿寺 断層での変動量はあつたにしても測定誤 差範囲内であるとされている。また1961 年から 1969 年の期間に気象打発行の地 震月報に掲載された震央分布をみると， Fig. 2 に示すようになる（伊藤, 1971）. この図に 1891 年の濃尾地震（マグニチ ュード8.4)，1945年の三河地震 (同7.1)。

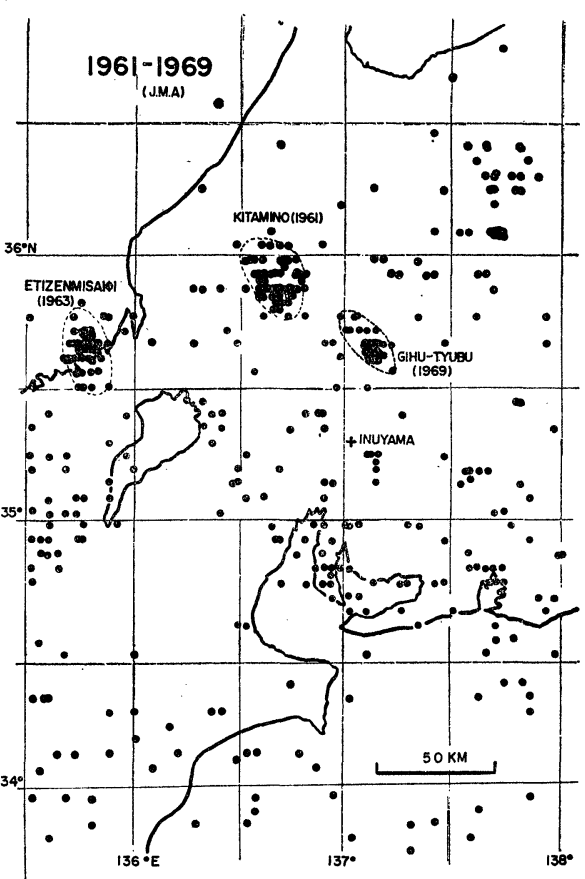

Fig. 2. Epicenter distribution from 1961 to 1969 determined by J. M. A.. Broken line shows aftershocks area of large earthquakes (after ITO, K., 1971). 


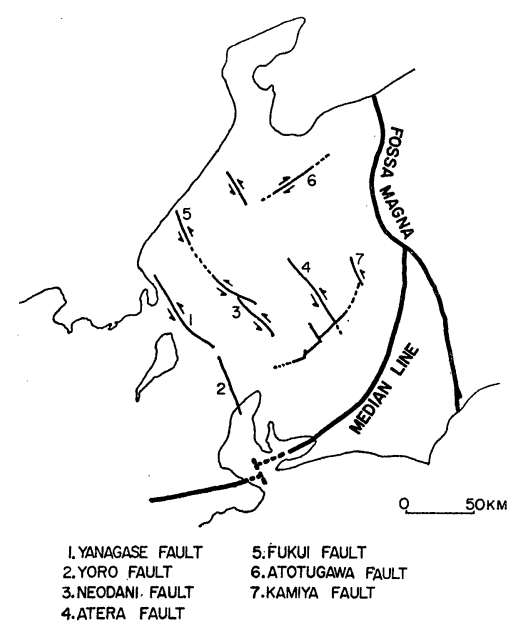

Fig. 3. Recent strike-slip faults in central Japan (Compiled from data of Sugimura, A. and T. MATSUDA, 1965).

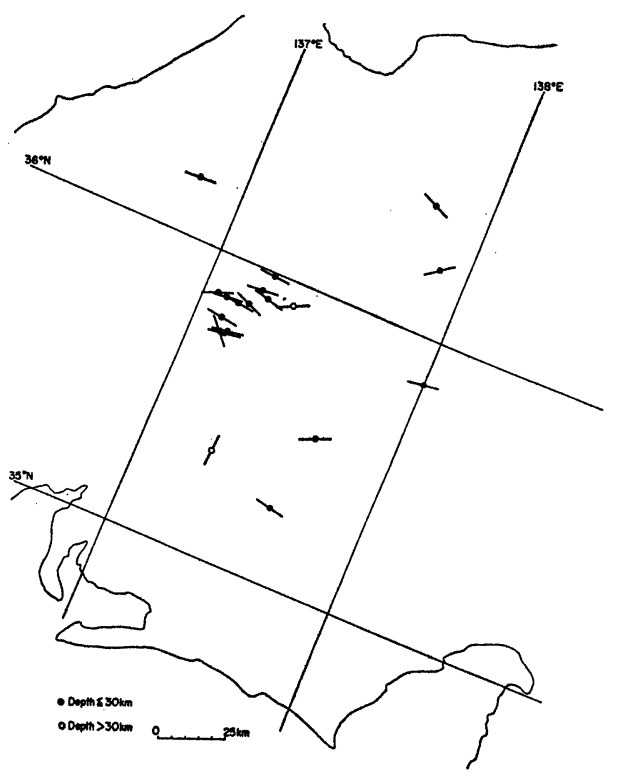

Fig. 5. Pressure axes of microearthquakes determined by the present observation.

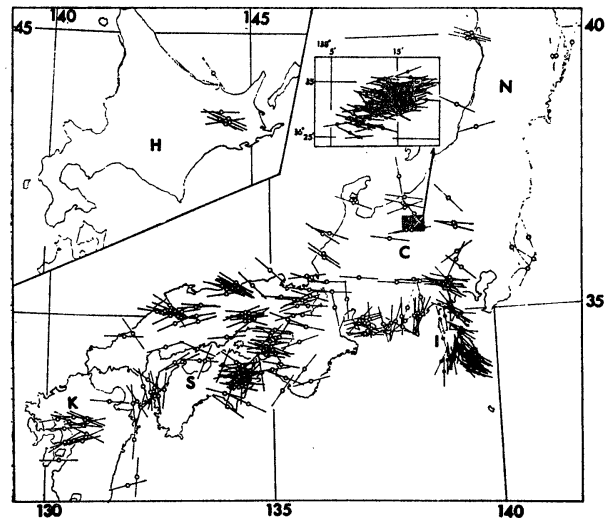

Fig. 4. Distribution of pressures for very shallow earthquakes. H: Hokkaido, I: Izu peninsula, S: Sanriku, K: Kyushu, C: Chubu, N: northern Honshu.

Pressure direction with solid circles in Shikoku indicate those of events occurred before 1947 (after ICHIKAwA, M., 1971).

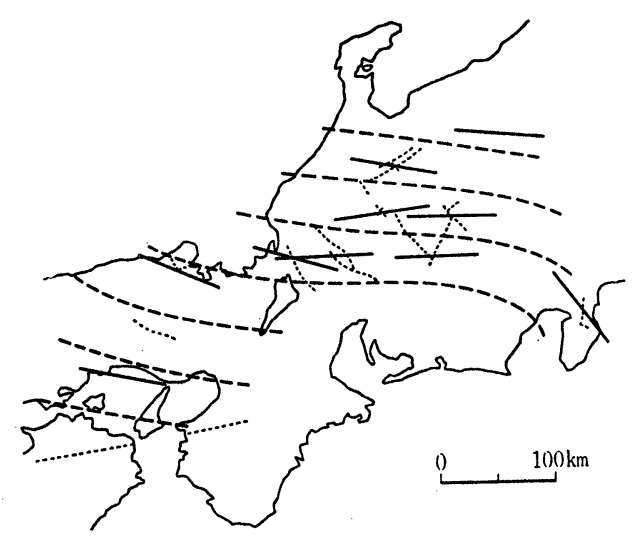

Fig. 6. Distribution of active faults (dotted lines), prssure directions (straight lines), and strike-slip faults and active faults (broken lines) (after MATSUADA, T., 1969). 


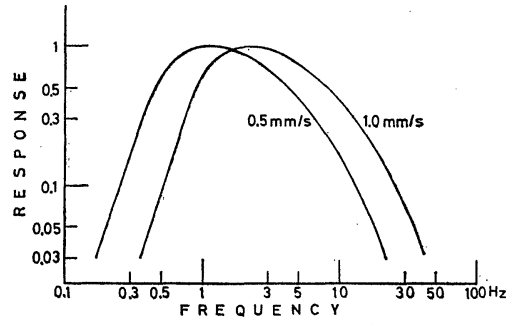

Fig. 7. Frequency responce of the data recording system. Tape speed is $1 \mathrm{~mm} / \mathrm{sec}$ or $0.5 \mathrm{~mm} /$ sec on recording and is $9.5 \mathrm{~cm} /$ sec on play back.

1948 年の福井地震（同 7.3） 1952 年の大聖寺地 震（同 6.8）の余震域を重ね合わせ考えるならば, この地域が微小地震から被害地震にいたるまであ らゆる地震の面からみてもいかに地震活動が低い かがわかると思ら。

\section{§3．中部地方に働く主圧縮力軸}

阿寺断層は前述したように地質学的地形学的に みて第一級の活断層であるといわれ，長期間变位速 度は $5 \mathrm{~mm} /$ 年 （松田，1969） と推定されている。中部地方には阿寺断層，根尾谷断層をはじ めとし, 跡津川断層, 柳ヶ瀬断層等が分布し (Fig. 3), これらの活断層は垂直変位に比べて 水平変位が数倍に達する横ずれ断層である，断層の走向は北西一南東と北東一南西のものが卓 越している，そして走向が北西一南東のものは左横ずれ断層であり，北東一南西のものは右横 ずれ断層である。また阿寺断層にそつては，これに付随する断層群および破砕帯が存在し，さ らにこの地域の基盤をなす岩盤の割れ目の方向を含め，この地域の地質構造には上記の北西一 南東, 北東一南西のものが卓越していることが指摘されている(村井，1970)。このような北西 一南東, 北東一南西の方向といらものは，東西方向に主圧縮力が働いた時にできる割れ目の共 役な 2 万向に対応するものであることがわかり，また各々の活断層の横ずれ方向も説明できる. よつてもしこの東西方向の主圧縮力によつて断層が変位し，地震を発生するものならば，北西 一南東拉よび北東一南西の 2 方向に節線をもつ四象限型の $\mathrm{P}$ 波初動の押し引き分布を示すであ ろうことが考えられる．実際にこの地域に発生した地震の押し引き分布を調へ，その主圧縮軸 の方向を求めると，浅発地震のものはほとんど東西方向を示すことが報告されている (Fig. 4. M. ICHIKAWA，1970). また微小地震から求めた主圧縮軸の方向も同じ傾向を示すことが大井 田・伊藤（1972）によつて指摘されている．Fig. 5. には今回の観測から求めることのできた 主圧縮軸の方向を示す。

松田（1969）は前述の横ずれ断層系から，中部日本の地殼内応力分布をもとめ Fig. 6. に示 す結果を報告している。

上述のように，この地域には東西方向の主圧縮力が作用していることは，地震学的にも構造 地質学的にも明らかであり, 現在の地質, 地款構造はこの主圧縮力によつて形成されたであろ うことが推定される. 


\section{$\S 4$. 調查方法}

今回の調査は $\S 2$. で述べたように少なくともこの 1000 年間は阿寺断層を 直接変位させ た被害地震が発生していなく，また過去 3 回にわたる微小地震観測からも地震活動が非常に低 いことがわかつていた地域での観測を実施し，この地域の地震活動を調べ今後この地域が地震 学的にみてどのような意味をもつてくるかを調べるための下準備となり，そのためにはどのよ らな手段，方法でもつて調査究明を行なつていけばよいかを見分けだすという目的のために必 然的に長期間にわたる観測を行ない十分な量の資料をあつめることが必要になる。このため筆 者等は長時間無人で連続観測のできる直接録音方式のデータレューダーを製作し，今回はこれ らを用いて，3点で臨時観測を行なつた。これらの臨時観測点としては阿寺断層付近の地震活 動を調査するためであるから断層近くに設定すること，また断層の北西部地域ではまだ 1969 年の岐阜県中部に発生した地震（東経 137.1 度，北緯 35.8 度，深さ $0 \mathrm{~km}$ ，マグニチニー ド 6.6) の余震が多発しているのでこの地域から遠ざかること, そして 1970 年 3 月には, 南東 端で臨時観測を行なつた経験があるということから，阿寺断層の南東端で 1 辺約 $20 \mathrm{~km}$ で観

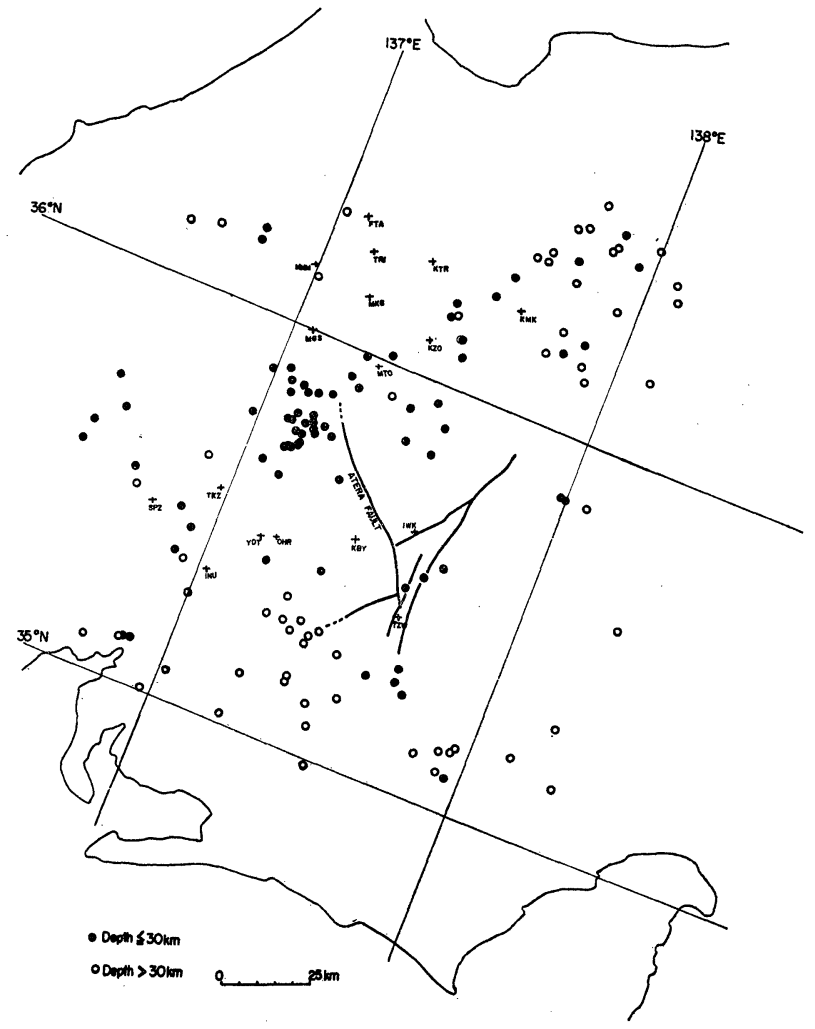

Fig. 8. Distribution of epicenters obtained from the present observation. + indicates locations of observation points. 
測点を 3 カ所選定した。 それぞれの観測点の地名は, 岐阜県恵那郡福岡町北林 (KBY), 長野県 西筑摩郡南木曾町三殿岩倉 (IWK), 長野県下伊那郡阿智村戸沢 (TZW) である。震源決定のさ いには，上記 3 観測点の他に犬山地震観測所 (INU) 特よびその衛星観測点，また筆者等の観 測期間とほぼ同時期に高山市周辺で，犬山地震観測所移動班と高山地震観測所によつて臨時観 測が行なわれた（山田，等，1972）ので，これらのデータをも借用した。 KBY, IWK, TZW における観測期間は Table 1. に揭げてある.

録音のさいには上記のデータレコーダが 4 チャンネル録音へッドを備えているので， 1 秒上 下動の地震計, 1 秒水平動の地震計を用いて行ない, 刻時は水晶時計, そして時刻の較正は NHK の時報を用いて行なつた．再生記録はビジグラフを用いて得た。録音時のテープスピードは $1 \mathrm{~mm} / \mathrm{sec}(0.5 \mathrm{~mm} / \mathrm{sec}$ でも可能)，再生時には $9.5 \mathrm{~cm} / \mathrm{sec}$ であり，この場合の総合周波数 特性を Fig. 7 に示す。な譄幅器の利得は $10 \mathrm{~Hz}$ で $80 \mathrm{db}$ のものを用いており, 再生のさ いには $4 \mathrm{~mm} / 100 \mu$ kine の值で使用した。 これらの録音，再生に関する詳細は伊神・青木

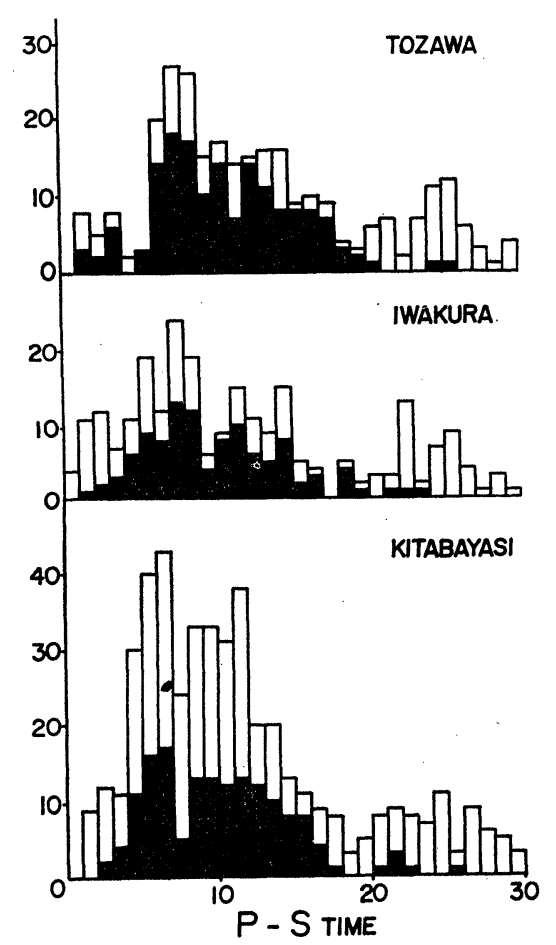

Fig. 9. Frequency of S-P times of microearthquakes detected at the three stations. Black parts show the frequency of earthquakes whose epicenters could be determined.

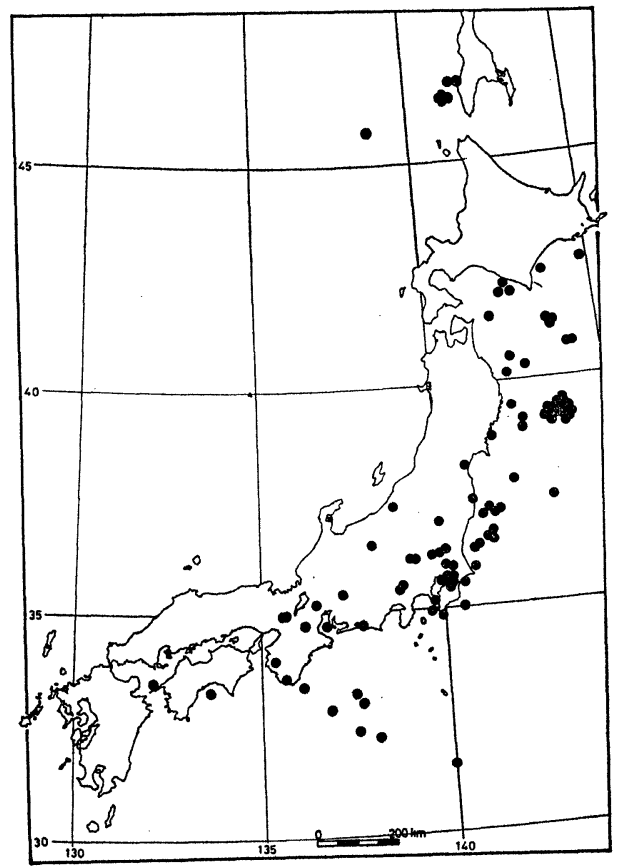

Fig. 10. Distribution of distant earthquakes detected in the present observation. Epicenters were determined by J. M. A. 
（1972）に報告がある.

\section{$\S 5$ ． 観 測 結果}

震源決定のさいには，すでに述べたように筆者らによる観測点（KBY，IWK，TZW）以外 の観測点の資料をも用いた．Fig. 8 の震央分布図にはこれらすべての観測点の位置，阿寺断 層の位置をも示す，震源決定は次の方法によつた。少なくても 1 点の観測点において S-P 時 間が 15 秒以下のものを取り出し，爆破動地震研究グループによる渥美・能登の測線での 結 果 (H. AoKI, et al., 1972) を考慮して， 3 層の水平成層を仮定し，P 波の着震時と S-P 時間 の直線関係より発震時をきめ, 走時曲線を計算し，この走時曲線と観測値との偏差が最小にな るという方法を用いた。 Fig. 8 から焼岳付近，岐阜県中部の地震の余震域 (Fig. 2 参照) に おいて地震活動がより大きいことがわかると同時に，阿寺断層付近では地震活動が非常に小さ いことがわかる．そしてこの断層の北東側は南西側に比べると，より不活発であることがわか る. また Fig. 8 には震源が $30 \mathrm{~km}$ 以浅のものと，それより深いものとにわけて表示してあ るが，阿寺断層の南西側の地域ではマントル内に発生した地震が多く，これらは直接阿寺断層 に関係する地震ではないと思われる，また阿寺断層の中央部，南東末端部およびその延長上に 数個震源のもとまつた浅い地震が存在するが，これらが本当に阿寺断層に関係するものである かどうか現在確かめる手段はない，北東側地域では南西側地域に比べて概して浅いが，これら の地震の断層までの震央距離および分布を考えると，これらも直接断層に関係するものとは言 い難い.

筆者らによる 3 観測点 $(\mathrm{KBY}, \mathrm{IWK}, \mathrm{TZW})$ における S-P 時間の度数分布をつくつたもの を Fig. 9 に示す。なお Fig. 9 には震源を求めるさいに使用した地震 (黒い部分) と，使用し なかつた地震（白い部分）とを区別して示しある。

この図から S-P 時間が数秒以下という観測点近くのものの度数が観測点とも少ないことに 注目できる。また特徵的なことは，3 観測点とも感度 はほぼ同じであるが，KBY に拈ける度数分布が他の 2 点に比べて多くなつていることである。このことは 各々の観測点地域の地質構造を反映しているのではな いかと思われる. IWK, TZW の 2 観測点は断層上も しくは断層破砕帯上に地震計を設置してしまつたが， KBY はこの阿寺断層周辺に広く分布している中生界 濃飛流紋岩を貫いた花崗斑岩の上に設置した。弾性波

Table 2. Ratio of detected earthquakes of long S-Ptimes with those determined by J. M. A. during the period listed in Table 1 .

\begin{tabular}{|clll|}
\hline Station July & Aug. & Sep. \\
\hline \multirow{2}{*}{ KBY } & $25 / 28$ & $33 / 44$ & $50 / 75$ \\
& $(89 \%)$ & $(75 \%)$ & $(67 \%)$ \\
IWK & $19 / 25$ & $29 / 44$ & $26 / 30$ \\
& $(76 \%)$ & $(66 \%)$ & $(89 \%)$ \\
TZW & $22 / 25$ & $29 / 44$ & $58 / 65$ \\
& $(88 \%)$ & $(66 \%)$ & $(77 \%)$ \\
\hline
\end{tabular}


速度, 波の減衰等は物質およびその状態によつて異なるであろらから, 地質構造が波の伝播に 大きな影響を与えた結果，上記の観測点で感知した地震数が少なくなつたのではないかと推定 できる。また気象庁によつて筆者らが観測した時期に日本周辺で発生した地震の震源が発表さ れているが，これらの地震のうち 3 観測点で感知したもの (Fig. 10) の割合を示すと Table 2 のようになる。

このように震央距離が大なる地震については， 3 観測点とも大きな差はないから地表近くの 地質構造が特に波の伝播に大きな影響をおよぼしているであろらと考えられる。また震央分布 図 (Fig. 8) からもわかるように筆者らの観測の結果, 震源は阿寺断層の西側の地域（1969 年 の岐阜県中部の地震の余震も含めて）に多く見られること，KBY の位置のみが断層の西側に 位置していることを考えあわせれば，上述のことは間違つてはいないと考えられる。

\section{$\S 6$. 結 論}

今回の微小地震活動の調査からは，阿寺断層付近での地震活動は非常に不活発であることが わかつた，地質学的地形学的にみて第 1 級の活断層であるといわれているこの阿寺断層付近の 地震活動が非常に不活発であるという事実はいくつかの問題点を含んでいるものと思われる.

第 1 に村松 (1971) が指摘しているような, 活断層である阿寺断層の地震活動が，ここ 1000 年間被害地震を発生していないこと，また微小地震の観測からもこの周辺では不活発であるこ とからこのような現在の阿寺断層の状態は大地震前の危険な兆候である，ということはいい きれるかどうか．松田（1969）はこの阿寺断層における地震の周期は, 地質学的資料および歪 速度から約 1000 年と推定している. しかしながら San Andreas Fault の一部には，クリープ 性の地殻変動が発見されてており (ALLEN, C. R., et al., 1965), 地殼に応力がかかつてもす ぐにその応力を解放するようにクリープすると考えられ，当然この地域では地震活動が小さく なつてくるはずである。な昖田（1969）は日本にはこのよらなクリープ性の断層は見つかつ ていないと指摘している。それゆえ微小地震観測からはこの地域の地震活動は小さいというこ とがわかつたから, 今後はさらに地震学的にこの地域の応力場と地殼構造との関係を明らかに していく必要があると思われる。この地域において東西方向の主圧縮力がかかつているのだか ら，この阿寺断層付近においてはこの応力を貯え続けているのか，または常時上記のクリープ 現象を示しているのかをはつきりさせる必要も生じてくる，たとえばこの阿寺断層の断層面が 非常に堅固な癒着状態を示しているならば，この地域にはそれなりの相当の応力が貯え続けら れてきたはずである。そしてこのような状態の地域を弾性波が伝播するさいにはなんらかの影 響を受けるはずである。実際に地震の前後で $V_{p} / V_{s}\left(V_{p}\right.$ は $\mathrm{P}$ 波の速度, $V_{s}$ は $\mathrm{S}$ 波の速度 $)$ 
の比が 10\% 程度異なつているとの報告がある（檀原，1971）。

第 2 に筆者らが設置した観測点 3 点のらち 2 点が断層上または断層破砕帯上にあり，他の 1 点は地質図上からはこのような傷だらけの地域ではなく，この 1 点だけ感知した地震数が多か つたということ。このことから地壳構造の弾性波におよぼす減衰の問題も生じてくると思われ る.

第 3 に十分な測地学的な資料，いいかえれば現在の動きを示す資料が必要になつてくる，現 在までこの阿寺断層付近では東京大学地震研究所の笠原等 $(1968,1969)$ によつて光波測量が 実施さており，また 1969 年の岐阜県中部地震の後にも測量が実施されてきた（笠原，等， 1970).この結果からこの阿寺断層からは有意な変動量は見いだされなかつたと報告されている.

このように地殼構造, 特に活断層とその付近における地震活動および応力場との関係, 地震 波の伝播等から，この地域が地震学的にみてどのような動き，状態を示しているかを明らかに していくことが必要であろらと考觉る。

最後にこの観測を実施し，その資料を解析するまでにいろいるとと御援助，資料をいただい た犬山および高山地震観測所の方々，教室の方々，そしていろいろ御世話下さつた現地の方々 に感謝します。震源決定のさいには名古屋大学計算機センターFACOM 230-60, 課題番号 4001 AV 0130 を使用した。

\section{文献}

Allen, C. R. et al., 1965, Relationship between Seismicity and Geologic Structure in the Southern California Region, Bull. Seism. Soc. Amer., 55, 753-797.

AokI, H. et al., 1972, Crustal Structure in the Profile Across Central Japan as Derived from Explosion Seismic Observation, Part 2. Crustal Structure, J. Phys. Earth, 20, in press. 檀原 毅, 1971, IUGG 総会の報告, 測地学会において報告.

ICHIKAWA, M., 1971, Reanalyses of Mechanism of Earthquakes which Occurred in and near Japan and Statistical Studies on the Nodal Plane Solutions Obtained 1926-1968, Geophys. Mag., 35, 207-274.

飯田汲事, 1972, 東海地方に㧍ける被害地震の活動, 災害科学シンポジウム論文集, 中部地区におけ る自然災害の実態と予測に関する総合研究報告, 34-44.

伊神 煇，青木治三，1972，微小地震観測のための長時間データレコーダ，地震 2, 25, 187-189.

伊藤 潔, 1971, 1969 年 9 月 9 日岐阜県中部地震の余震活動, 地震 $2,24,117-128$.

笠原慶一, 岡田 惊, 1966, 光波測量に上る地殼変動の観測，第 1 報，中部日本に淤る基線網設定， 地震研究所異報, 44, 1149-1165.

笠原慶一他, 1968, 光波測量による地殼変動の観測, 第 2 報, 関東中部地方に批る基線網の増設と 観測結果 (昭和 41,42 年度), 地震研究所彙報, 6, 741-758,

- 1969 , 光波測量による地呍変動の観測, 第 3 報, 既設基線網の再測ならびに中型基線網の 設定 (昭和 43 年度), 地震研究所畄報, $47,803-818$.

-, 1970 , 光波測量による地殼変動の観測, 第 4 報, 既設基線網の再測（昭和 44 年度，地震 研究所彙報, 48, 999-1008.

1970, 阿寺断層に批る光波測量, 地震研究所菓報, 48, 1235-1240.

松田時彦, 1969, 活断層と大地震, 科学, 39, 398-407. 
村井 勇, 1970, 岐阜県中部地震一1969 年 9 月 9 日一の地震地域およびその周辺の地質構造, 地震 研究所彙報, 48, 1251-1266.

村松有栄, 1971, 阿寺断層付近の微小地震活動について, 濃尾平野シンポジウム資料, 87-90.

大井田徹, 山田功夫, 1971, 中部地方の微小地震活動 (1)一根尾谷断層周辺の微小地震活動一, 地震 2 , 24, 240-247.

Sugrmura, A. and T. MAtsuda, 1965, Atera Fault and its Displacement Vectors, Geol. Soc. Amer. Bull., 76, 509-522.

渡辺史郎, 飯田汲事, 1970, 阿寺断層付近の微小地震活動, 地震 2, 22, 348-349.

山田功夫 他, 1972, 飛驒地方の微小地震活動, 地震 2, 25, 124-133.

Utsu, T., 1969, Aftershocks and Earthquake Statistics (I), Some Parameters Which Characterize an Aftershock Sequence and Their Interrelations, J. Fac. Sci. Hokkaido Univ. VII, 3, 129-195. 